\title{
Asymmetric Synthesis of Cyclic Alkenes via Cyclization of Enantioenriched Allylsilanes
}

\author{
Michinori Suginome, * Taisuke Iwanami, Akihiko Yamamoto, Yoshihiko Ito* \\ Department of Synthetic Chemistry and Biological Chemistry, Graduate School of Engineering, Kyoto University, Kyoto 606-8501, Japan \\ Fax +81(75)7535668; E-mail: suginome@ @bchem.kyoto-u.ac.jp \\ Received February 23, 2001
}

\begin{abstract}
Intramolecular cyclizations of optically active allylsilanes bearing electrophilic functional groups on their $\alpha$-alkyl side chains were examined. The allylsilanes having aldehyde and enone functional groups underwent the intramolecular cyclizations in the presence of Lewis acid catalysts to give 6- and 7-membered cycloalkenes with high stereoselectivity in good yields. Reactions of the allylsilanes having $\alpha$-hydroxyalkyl chain with aldehydes provided 6- and 7-membered oxacycloalk-4-enes stereoselectively in good yields. Use of highly enantioenriched allylsilanes furnished enantioenriched cyclic alkenes with almost perfect chirality transfer from the allylsilanes.
\end{abstract}

Key words: allylations, chirality transfer, Lewis acids, silicon, stereoselective synthesis

Allylsilanes have been widely utilized in organic synthesis owing to the highly regio- and stereoselective C-C bond formations in their reactions with carbon electrophiles. Besides the intermolecular allylations with allylsilanes, intramolecular cyclization of allylsilanes bearing electrophilic functional groups has enabled efficient synthesis of cyclic compounds, including cycloalkenes, alkylidenecycloalkanes, and alkenylcycloalkanes, depending upon the functionalized starting allylsilanes (Scheme 1). ${ }^{1}$

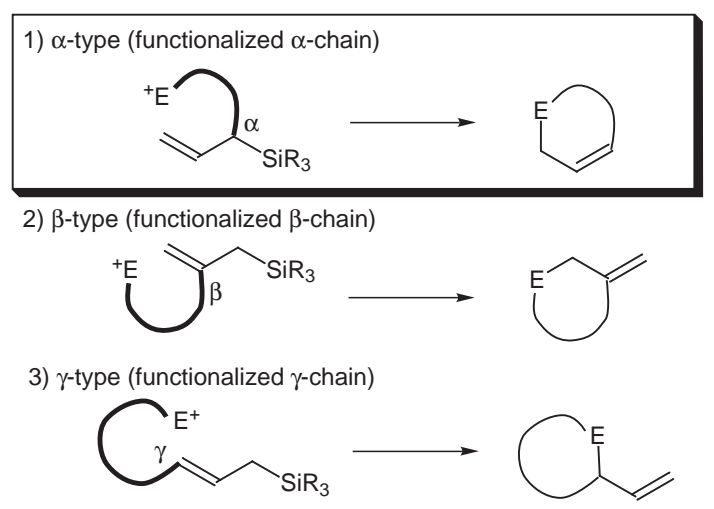

Scheme 1 Classification of Lewis Acid-Promoted Allylsilane Cyclization

The use of enantioenriched allylsilanes in the intramolecular cyclization has been potentially useful for the asymmetric synthesis of cyclic compounds, since the allylative cyclization may proceed with stereoselective 1,3-chirality transfer. ${ }^{2,3}$ However, the asymmetric version of the allyl- silane cyclization has been so far limited, due to the lack of convenient synthetic access to the functionalized allylsilanes.

Recently, we have developed new methodology for the general synthesis of highly enantioenriched allylsilanes, in which palladium-catalyzed intramolecular bis-silylation of optically active allylic alcohols is involved as a key step (Scheme 2). ${ }^{4}$ Of particular interest is that the synthesis of $(E)$-allylsilanes was accomplished with nearly perfect 1,3-chirality transfer from the allylic alcohols. With the practically useful method in our hands, we have succeeded in the synthesis of enantioenriched allylsilanes having hydroxyalkyl groups at the $\gamma$-allylic carbon atoms. The allylsilanes underwent Lewis acid-catalyzed cyclization with carbonyl compounds, giving optically active cyclic compounds through $\gamma$-type cyclization with nearly perfect chirality transfer. ${ }^{5}$ Herein, we describe $\alpha$-type cyclization of enantioenriched allylsilanes bearing electrophilic functional groups, which provide cyclic alkenes stereoselectively with efficient chirality transfer.

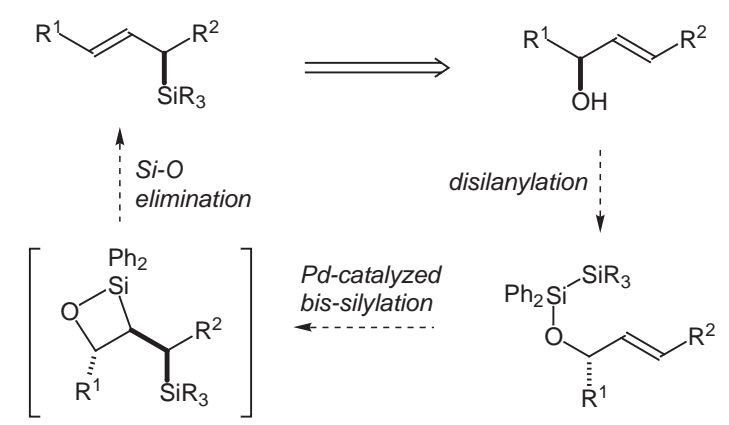

Scheme 2 Synthesis of Enantioenriched Allylsilanes via BisSilylation

An outline of the synthesis of $\alpha$-functionalized allylsilanes is shown in Scheme 3. The allylic alcohols bearing an $\omega$-tetrahydropyranyloxy group were transformed to the corresponding disilanyl ethers and subjected to the intramolecular bis-silylation reaction in the presence of a palladium-isonitrile catalyst. Subsequent treatment of the crude reaction mixture with $n$-BuLi followed by deprotection of the THP group with pyridinium $p$-toluene sulfonate afforded allylsilanes bearing hydroxyalkyl $\alpha$-chains. According to the procedure, enantioenriched allylsilanes were prepared stereoselectively with $>99 \%$ 
chirality transfer from the starting optically active allylic alcohols. Allylsilanes bearing aldehyde and enone functional groups on the $\alpha$-alkyl side chains were prepared from the corresponding alcohol precursors via Swern oxidation and subsequent Horner-Emmons olefination.

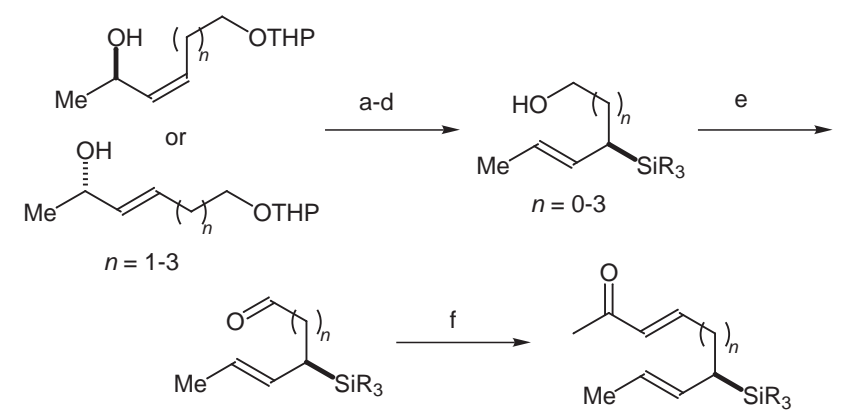

Scheme 3 Outline of the Synthesis of Chiral Allylsilanes Bearing Functionalized $\alpha$-Chains

Initially, we examined the Lewis acid-catalyzed intramolecular cyclization of the aldehyde derivatives $\mathbf{1}$ and $\mathbf{3}$ (Table 1). Among the Lewis acids tested, trimethylsilyl triflate (TMSOTf) was effective for both the cyclizations to give the corresponding 2-methyl-3-cycloalken-1-ols 2 and 4 in moderate-to-good yield (entries 1 and 3). ${ }^{6}$ It is noteworthy that the seven-membered ring formation took place with almost complete trans-selectivity, whereas the six-membered ring formation proceeded with moderate cis-selectivity, ${ }^{7}$ which was improved to $92: 8$ by using $\mathrm{TiCl}_{4}$ as Lewis acid under otherwise the same reaction conditions (entry 2). Under the optimized reaction conditions, enantioenriched $(R$ )-allylsilanes $\mathbf{1}$ and $\mathbf{3}$ (both $93.6 \%$ ee) afforded the respective products $(1 R, 2 S)$ - $\mathbf{2}$ and $(I S, 2 S)-\mathbf{4}$ with complete conservation of the enantiopurity of the starting allylsilanes. ${ }^{10,11}$

Intramolecular $\alpha$-type cyclization of enone-allylsilanes 5 and 7 also proceeded in the presence of Lewis acids to provide trans-3,4-disubstituted cycloalkenes $\mathbf{6}$ and $\mathbf{8}$ selectively (entries 5-10). Although the six-membered ring formation took place with moderate stereoselectivity up to 12:88 in the $\mathrm{AlCl}_{3}$-catalyzed reaction (entry 7), extremely high stereoselectivity as well as high yield was attained in the cyclization of $\mathbf{7}$ in the presence of $\mathrm{TiCl}_{4}$ or TMSOTf (entries 8 and 9). ${ }^{12}$

Reaction of $\alpha$-hydroxyalkyl-substituted allylsilane 9 with acetaldehyde was carried out in the presence of TMSOTf at $-78{ }^{\circ} \mathrm{C}$ (Scheme 4 , Table 2, entry 1), affording trans3,4-disubstituted 5-oxacycloheptene 10a diastereoselectively in good yield with perfect chirality transfer. ${ }^{13-15} \mathrm{An}$ $\alpha$-branched aliphatic aldehyde, an aromatic aldehyde, and an $\alpha, \beta$-unsaturated aldehyde also afforded the corresponding oxacycloheptenes 10b-d with high enantiopurity in high yields. It is noteworthy that the use of the trimethylsilyl derivative rather than higher alkyl-substituted silyl derivatives made the isolation process simple because of
Table 1 Stereoselective Synthesis of Cyclic Alkenes via Cyclization of Chiral Allylsilanes ${ }^{a}$

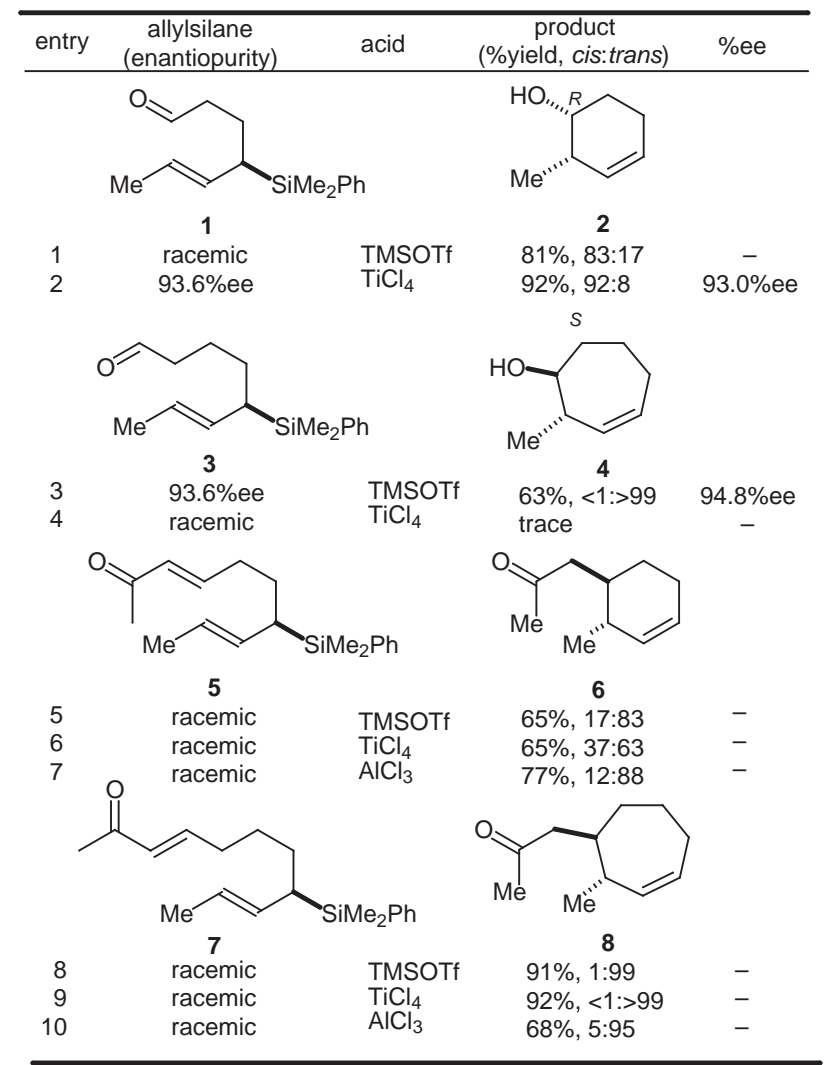

${ }^{a} \mathrm{At}-78^{\circ} \mathrm{C}$. For detailed reaction conditions, see note 6 .

${ }^{b}$ Isolated yield.

${ }^{c}$ Determined by capillary GC.

${ }^{d}$ Determined by chiral GC.

the high volatility of the silicon-containing by-products. Thus, essentially pure $\mathbf{1 0}$ was obtained after extraction and evaporation.
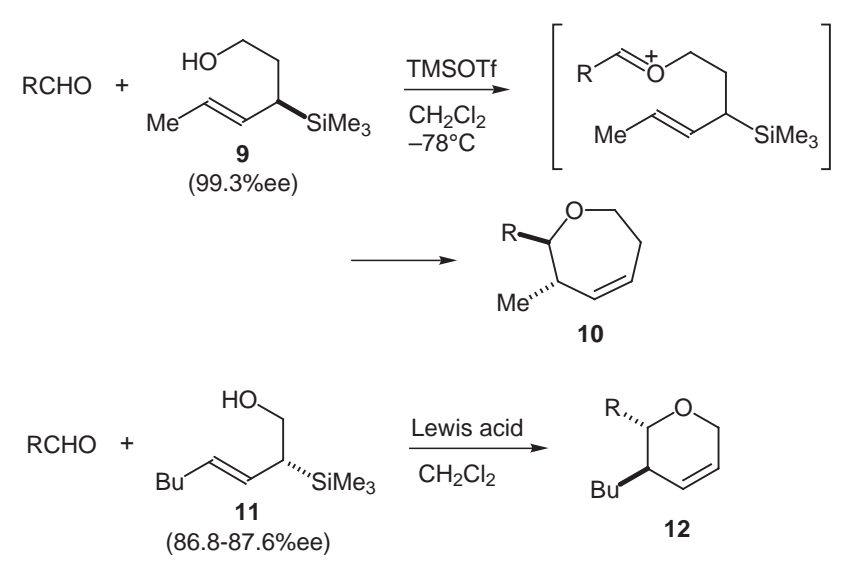

Scheme 4 Cyclization of Hydroxyalkyl-Substituted Allylsilanes with Aldehydes 
Table 2 TMSOTf-Promoted Reaction of $(R)-9$ (99.3\% ee) with Aldehydes Giving 10. ${ }^{\mathrm{a}}$

\begin{tabular}{ccccc}
\hline entry & $\begin{array}{c}\text { aldehyde } \\
(\mathrm{RCHO})\end{array}$ & $\begin{array}{c}\text { product } \\
\left.\text { (yield, }^{b} \text { cis:trans }^{c}\right)\end{array}$ & \%ee $^{d}$ & $\begin{array}{c}\text { \%chirality } \\
\text { transfer }\end{array}$ \\
\hline 1 & MeCHO & 10a $\left(94 \%,{ }^{e} 3: 97\right)$ & 99.0 & 99.7 \\
2 & $c$-HexCHO & $\mathbf{1 0 b}(92 \%, 4: 96)$ & 99.2 & 99.9 \\
3 & PhCHO & $\mathbf{1 0 c}(94 \%, 2: 98)$ & 99.1 & 99.8 \\
4 & $(E)-\mathrm{PrCH}=\mathrm{CHCHO}$ & $\mathbf{1 0 d}(83 \%, 5: 95)$ & 99.3 & $>99.9$ \\
\hline
\end{tabular}

${ }^{a} \mathrm{At}-78{ }^{\circ} \mathrm{C}$. For detailed reaction conditions, see note 13 .

${ }^{b}$ Isolated yield unless otherwise noted.

${ }^{c}$ Determined by capillary GC.

${ }^{d}$ Determined by chiral capillary GC or HPLC.

${ }^{e} \mathrm{GC}$ yield.

Then, reactions of the aldehydes with allylsilane $\mathbf{1 1}$ having a shorter $\alpha$-chain were carried out under the same reaction conditions as those for the seven-membered ring formation (Scheme 4), providing trans-disubstituted oxacyclohexenes $\mathbf{1 2}$ in slightly lower yields and diastereoselectivities than the corresponding seven-membered ring formation (Table 3). The lower yield may be due to the minor formation of 1,3-pentadiene via acid-induced Peterson-type elimination. On the other hand, nonbranched aliphatic aldehyde gave the cyclized product with significantly lower ee ( $7 \%$ decrease) than that of the starting allylsilane (entry 1). The decrease in ee may be attributed to the minor syn-attack pathway, which has generally been considered unusual for the reaction of allylsilanes. ${ }^{16}$ The involvement of the $s y n$-attack pathway has only recently been described by Panek et al. for the related oxacyclohexene formation using enantioenriched allylsilanes bearing hydroxyalkyl $\alpha$-chain with an additional stereogenic center. ${ }^{3 \mathrm{~d}}$ We found that the undesired syn-attack pathway can be completely suppressed by use of other Lewis acids such as $\mathrm{TiCl}_{2}(\mathrm{OPr}-i)_{2}$ and $\mathrm{AlCl}_{3}$. Although the use of the former resulted in moderate yield, the latter afforded 12a in good yield with perfect chirality transfer. Since the highly stereoselective anti-attack pathway was demonstrated by Hayashi and Kumada, ${ }^{2}$ the possibility of the syn-attack pathway has not been taken into consideration or examined carefully in the reactions of enantioenriched allylsilanes. Our results suggest that the appropriate use of Lewis acid is highly important to realize perfect chirality transfer in the reactions of enantioenriched allylsilanes.

\section{Acknowledgement}

This work was supported by Grant-in-Aids from Ministry of Education, Culture, Sports, Science, and Technology, Japan. T. I. acknowledges fellowship support of the Japan Society for the Promotion of Science for Japanese Young Scientists.
Table 3 Lewis Acid-Promoted Reaction of $(S)$-11 (86.8-87.6\% ee) with Aldehydes Giving 12. ${ }^{a}$

\begin{tabular}{ccccc}
\hline entry & $\begin{array}{c}\text { aldehyde } \\
\text { (RCHO) }\end{array}$ & Lewis acid & $\begin{array}{c}\text { product } \\
\left.\text { (yield, }{ }^{b} \text { cis:trans }{ }^{c}\right)\end{array}$ & $\begin{array}{c}\text { \%chirality } \\
\text { transfer }\end{array}$ \\
\hline 1 & $n$-HexCHO & TMSOTf & 12a $(77 \%, 10: 90)$ & 93.0 \\
$2^{d}$ & $n$-HexCHO & TiCl $_{2}(\mathrm{OPr}-i)_{2}$ & $\mathbf{1 2 a}(41 \%, 5: 95)$ & $>99.9$ \\
$3^{d}$ & $n$-HexCHO & $\mathrm{AlCl}_{3}$ & $\mathbf{1 2 a}(81 \%, 9: 91)$ & 99.7 \\
4 & $c$-HexCHO & TMSOTf $^{-}$ & $\mathbf{1 2 b}(83 \%, 11: 89)$ & 98.1 \\
5 & PhCHO & TMSOTf & $\mathbf{1 2 c}(56 \%, 8: 92)$ & $>99.9$ \\
\hline
\end{tabular}

${ }^{a}$ Allylsilane (S)-11 of $86.8 \%$ ee (for entry 3 ) or $87.6 \%$ ee (for other entries) was used. Reactions were conducted at $-78^{\circ} \mathrm{C}$ unless otherwise noted. For detailed reaction conditions, see note 13 .

${ }^{b}$ Isolated yield.

${ }^{c}$ Determined by capillary GC.

${ }^{d}-78{ }^{\circ} \mathrm{C}-$ room temperature.

\section{References and Notes}

(1) (a) Fleming, I.; Dunogues, J.; Smithers, R. Org. React. 1989, 37, 57. (b) Langkopf, E.; Schinzer, D. Chem. Rev. 1995, 95, 1375.

(2) For the stereochemical aspects in the reactions of enantioenriched allylsilanes, see: (a) Hayashi, T.; Konishi, M.; Kumada, M. J. Am. Chem. Soc. 1982, 104, 4963. (b) Hayashi,T.; Konishi, M.; Kumada, M. J. Org. Chem. 1983, 48, 281.

(3) Examples of intramolecular cylization of enantioenriched allylsilanes: (a) Mikami, K.; Maeda, T.; Kishi, Y.; Nakai, T. Tetrahedron Lett. 1984, 25, 5151. (b) Denmark, S. E.; Almsted, N. G. J. Org. Chem. 1997, 62, 9335. (c) Masse, C. E.; Dakin, L. A.; Knight, B. S.; Panek, J. S. J. Org. Chem. 1997, 62, 9335. (d) Huang, H.; Panek, J. S. J. Am. Chem. Soc. 2000, 122, 9836.

(4) (a) Suginome, M.; Matsumoto, A.; Ito, Y. J. Am. Chem. Soc. 1996, 118, 3061. (b) Suginome, M.; Iwanami, T.; Matsumoto, A.; Ito, Y. Tetrahedron: Asymmetry 1997, 8, 859.

(5) (a) Suginome, M.; Iwanami, T.; Ito, Y. J. Org. Chem. 1998, 63, 6096. (b) Suginome, M.; Iwanami, T.; Ito, Y. Chem. Commun. 1999, 2357.

(6) General procedure for the Lewis-acid promoted cyclization of $\mathbf{1}, \mathbf{3}, \mathbf{5}$, and 7 . To a solution of the allylsilanes $(0.21 \mathrm{mmol})$ in $\mathrm{CH}_{2} \mathrm{Cl}_{2}(4 \mathrm{~mL})$ was added Lewis acid $(0.23 \mathrm{mmol})$ in $\mathrm{CH}_{2} \mathrm{Cl}_{2}$ at $-78^{\circ} \mathrm{C}$. The mixture was stirred for $30 \mathrm{~min}$ at $-78^{\circ} \mathrm{C}$. Aqueous $\mathrm{NaOH}(1 \mathrm{M})$ was added at $-78^{\circ} \mathrm{C}$, and the mixture was warmed to room temperature with stirring. Extractive workup with ether followed by silica gel column chromatography afforded the corresponding products $2,4,6$, and 8. Spectral data for the products: $(1 R, 2 S)-2-$

Methylcyclohex-3-en-1-ol (2, Registry number: [81452-746]). ${ }^{1} \mathrm{H}$ NMR $\delta 1.03(\mathrm{~d}, \mathrm{~J}=7.4 \mathrm{~Hz}, 3 \mathrm{H}), 1.37-1.45(\mathrm{~m}, 1 \mathrm{H})$, $1.49-2.28(\mathrm{~m}, 4 \mathrm{H}), 2.28-2.29(\mathrm{~m}, 4 \mathrm{H}), 2.29-2.48(\mathrm{~m}, 1 \mathrm{H})$, 3.87-3.99 (m, 1H), 5.38-5.51 (m, 1H), 5.58-5.71 (m, 1H). $(1 S, 2 S)$-2-Methylcyclohept-3-en-1-ol (4): ${ }^{1} \mathrm{H}$ NMR $\delta 1.12$ (d, $J=6.9 \mathrm{~Hz}, 3 \mathrm{H}), 1.37-1.78(\mathrm{~m}, 4 \mathrm{H}), 1.94-2.19$ (m, 3H), 2.35$2.50(\mathrm{~m}, 1 \mathrm{H}), 3.30-3.42(\mathrm{~m}, 1 \mathrm{H}), 5.36(\mathrm{ddd}, J=11.4,7.8,2.1$ $\mathrm{Hz}, 1 \mathrm{H}), 5.82$ (dddd, $J=11.4,6.9,5.7,2.1 \mathrm{~Hz}$ ) ${ }^{13} \mathrm{C}$ NMR $\delta$ 18.3, 23.8, 28.0, 39.2, 40.6, 73.6, 132.6, 134.1. HRMS calcd for $\mathrm{C}_{8} \mathrm{H}_{14} \mathrm{O}\left(\mathrm{M}^{+}\right)$: 126.1045 . Found: 126.1043. $\left(3 S^{*}, 4 R^{*}\right)-3-$ 
Methyl-4-(2-oxopropyl)cyclohex-1-ene (6): ${ }^{1} \mathrm{H}$ NMR $\delta 0.99$ $(\mathrm{t}, J=7.0 \mathrm{~Hz}, 2 \mathrm{H}), 1.27$ (ddt, $J=13.0,5.9,8.8 \mathrm{~Hz}, 1 \mathrm{H}), 1.78$ $1.90(\mathrm{~m}, 3 \mathrm{H}), 1.93-2.06(\mathrm{~m}, 2 \mathrm{H}), 2.15(\mathrm{~s}, 3 \mathrm{H}), 2.27(\mathrm{dd}$, $J=16.3,8.4 \mathrm{~Hz}, 1 \mathrm{H}), 2.60(\mathrm{dd}, J=16.3,4.6 \mathrm{~Hz}, 1 \mathrm{H}), 5.46$ $(\mathrm{dq}, J=9.9,2.4 \mathrm{~Hz}, 1 \mathrm{H}), 5.60-5.66(\mathrm{~m}, 1 \mathrm{H}) ;{ }^{13} \mathrm{C} \mathrm{NMR} \delta 20.2$, 24.0, 26.7, 30.4, 35.2, 36.2, 48.3, 126.1, 132.4, 209.3. HRMS calcd for $\mathrm{C}_{10} \mathrm{H}_{16} \mathrm{O}\left(\mathrm{M}^{+}\right)$: 152.1201 . Found: 152.1199 . $\left(3 S^{*}, 4 R^{*}\right)$-3-Methyl-4-(2-oxopropyl)cyclohept-1-ene $(\mathbf{8}):{ }^{1} \mathrm{H}$ NMR $\delta 1.04(\mathrm{~d}, J=6.9 \mathrm{~Hz}, 3 \mathrm{H}), 1.38-1.65(\mathrm{~m}, 3 \mathrm{H}), 1.77-1.93$ (m, 1H), 1.95-2.15 (m, 3H), $2.12(\mathrm{~s}, 3 \mathrm{H}), 2.16-2.30(\mathrm{~m}, 1 \mathrm{H})$, 2.34 (dd, $J=16.2,7.8 \mathrm{~Hz}, 1 \mathrm{H}), 2.54(\mathrm{dd}, J=16.2,6.0 \mathrm{~Hz}$, $1 \mathrm{H}), 5.49(\mathrm{dd}, J=11.4,6.0 \mathrm{~Hz}, 1 \mathrm{H}), 5.70(\mathrm{dt}, J=11.4,5.7 \mathrm{~Hz}$, $1 \mathrm{H}) ;{ }^{13} \mathrm{C}$ NMR $\delta 19.4,23.8,28.3,30.4,33.1,37.5,37.8,48.5$, 130.5, 136.1, 209.4. HRMS calcd for $\mathrm{C}_{11} \mathrm{H}_{18} \mathrm{O}\left(\mathrm{M}^{+}\right)$: 166.1358. Found: 166.1359 . Note: $\mathrm{CDCl}_{3}$ was used for all the NMR measurements (300 MHz for ${ }^{1} \mathrm{H}$ and $75 \mathrm{MHz}$ for ${ }^{13} \mathrm{C}$ ).

(7) Panek et al. reported that the cyclization of $\mathbf{1}$ under essentially the same reaction condition as ours afforded trans- $\mathbf{2}$ with high (>30:1) diastereoselectivity. ${ }^{3 \mathrm{c}}$ In sharp contrast to their result, we established the stereochemistry of our product 2 was cis instead of trans by comparison of NMR data reported by Danheiser et al. ${ }^{8}$ as well as determination of the absolute configuration of $R$ at 1-position according to the methoxymanderate method. ${ }^{9}$

(8) Danheiser, R. L.; Davila, C.-M.; Sard, H. Tetrahedron 1981, 37, 3943.

(9) Trost, B. M.; Belletire, J. L.; Godleski, S.; McDougal, P. G.; Balkovec, J. M. J. Org. Chem. 1986, 51, 2370.

(10) The enantiomeric excesses of $\mathbf{2}$ and $\mathbf{4}$ were determined by chiral GC analyses with a Chrompack Cyclodextrine- $\beta$ 236M-19 capillary column.

(11) $\mathrm{The} \mathrm{TiCl}_{4}$-catalyzed reaction of $\mathbf{3}$ afforded only a trace amount of $\mathbf{4}$ along with two silicon-containing compounds which have been unidentifiable so far (entry 4).

(12) We have so far not been able to establish the GC or HPLC conditions for the ee determination of 6 and $\mathbf{8}$.

(13) General procedure for the Lewis-acid promoted cyclization of $\mathbf{9}$ and $\mathbf{1 1}$ with aldehydes. To a solution of the allylsilanes $(0.23$ $\mathrm{mmol})$ in $\mathrm{CH}_{2} \mathrm{Cl}_{2}(4 \mathrm{~mL})$ were added aldehydes $(0.26 \mathrm{mmol})$ and Lewis acid $(0.25 \mathrm{mmol})$ at $-78^{\circ} \mathrm{C}$. The mixture was stirred for $1 \mathrm{~h}$ at $-78{ }^{\circ} \mathrm{C}$. Aqueous $\mathrm{NaOH}(2 \mathrm{M})$ was added at $-78{ }^{\circ} \mathrm{C}$, and the mixture was warmed to room temperature with stirring. Extractive workup with ether followed by silica gel column chromatography afforded the corresponding products $\mathbf{1 0}$ and 12. Spectral data for the representative products: 2-Cyclohexyl-3-methyl-2,3,6,7-tertahydrooxepine (10b): ${ }^{1} \mathrm{H}$ NMR $\delta 0.97$ (d, $\left.J=7.2 \mathrm{~Hz}, 3 \mathrm{H}\right), 1.09-1.34$ (m, 4H), $1.40-1.53(\mathrm{~m}, 3 \mathrm{H}), 1.56-1.81(\mathrm{~m}, 4 \mathrm{H}), 2.11-2.24(\mathrm{~m}, 1 \mathrm{H})$, 2.27-2.42 (m, 1H), 2.43-2.60 (m, 1H), $2.92(\mathrm{~d}, J=9.3 \mathrm{~Hz}$, $1 \mathrm{H}), 3.39$ (ddd, $J=3.3,9.3,12.0 \mathrm{~Hz}, 1 \mathrm{H}), 4.02(\mathrm{dt}, J=12.0$, $4.5 \mathrm{~Hz}, 1 \mathrm{H}), 5.41-5.51(\mathrm{~m}, 1 \mathrm{H}), 5.59-5.72(\mathrm{~m}, 1 \mathrm{H}) ;{ }^{13} \mathrm{C} \mathrm{NMR}$ $\delta 18.4,25.2,26.5,26.6,26.7,30.8,31.5,38.1,40.0,70.1,88.8$, 127.4, 137.8. HRMS calcd for $\mathrm{C}_{13} \mathrm{H}_{22} \mathrm{O}\left(\mathrm{M}^{+}\right)$: 194.1671 . Found: 194.1671. 2-Cyclohexyl-3-methyl-3,6-dihydro-2 $\mathrm{H}$ pyran (12b): ${ }^{1} \mathrm{H}$ NMR $\delta 0.90(\mathrm{t}, J=7.2 \mathrm{~Hz}, 3 \mathrm{H}), 1.06-1.88(\mathrm{~m}$, $17 \mathrm{H}), 2.13-2.26(\mathrm{~m}, 1 \mathrm{H}), 3.05(\mathrm{dd}, J=7.5,3.6 \mathrm{~Hz}, 1 \mathrm{H}), 3.96-$ $4.18(\mathrm{~m}, 2 \mathrm{H}), 5.66-5.80(\mathrm{~m}, 2 \mathrm{H}) ;{ }^{13} \mathrm{C}$ NMR $\delta 14.0,23.0,26.4$, 26.48, 26.51, 26.7, 28.4, 30.7, 31.7, 35.0, 38.3, 64.7, 81.8, 125.7, 129.2. HRMS calcd for $\mathrm{C}_{15} \mathrm{H}_{26} \mathrm{O}\left(\mathrm{M}^{+}\right): 222.1982$. Found: 222.1984.

(14) The same transformation was reported with the allylsilane supported on the polymer resin. Suginome, M.; Iwanami, T.; Ito, Y. J. Am. Chem. Soc. 2001, 123, 4356.

(15) The enantiomeric excesses of the products $\mathbf{1 0 a}, \mathbf{b}$, and $\mathbf{d}$ were determined by chiral GC analyses with a Chrompack Cyclodextrine- $\beta-236 \mathrm{M}-19$ capillary column. The compounds 10c and 11a-c were subjected to hydroboration with 9-BBN followed by $\mathrm{H}_{2} \mathrm{O}_{2}$ oxidation. The resultant cycloalkanols bearing a hydroxy group at 5-position were isolated by HPLC (silica gel) and transformed into the corresponding 3,5dinitrophenylcarbamates, which were subjected to chiral HPLC analyses with Sumichiral OA-4500 columns.

(16) Buckle, M. J. C.; Fleming, I.; Gil, S. Tetrahedron Lett. 1992, 33, 4479.

Article Identifier:

1437-2096,E;2001,0,SI,1042,1045,ftx,en;Y06501ST.pdf 